\title{
Which near-patient tests might improve the diagnosis of UTI in older people in urgent care settings?
}

\section{A mapping review and consensus process}

\section{Title}

Which near-patient tests might improve the diagnosis of UTI in older people in urgent care settings? A mapping review and consensus process

\section{Running title}

Near patient tests for urinary tract infection in older people.

\section{Authors}

Molly Jameson (mhj8@student.le.ac.uk) ${ }^{1}$; Mary Edmunds Otter (maryeo001@gmail.com) ${ }^{1}$; Christopher Williams (cdw4@leicester.ac.uk) ${ }^{1}$; Deborah Modha (deborah.e.modha@uhl-tr.nhs.uk)'; Felicia Lim (felicia.h.lim@uhltr.nhs.uk) ${ }^{2}$; Simon P Conroy (spc3@le.ac.uk) ${ }^{1^{*}}$.

1. Department of Health Sciences, University of Leicester

2. Department of Microbiology, University Hospitals of Leicester

*Corresponding author: Simon P Conroy, Room 3.37, George Davies Centre, University of Leicester, University Road, Leicester, LE1 7RH. T: 00441162525992; E: spc3@le.ac.uk; Tw: @GERED_ED. ORCID ID: 0000-00024306-6064

\section{Key words}

- Older people

- Urinary tract infection

- Systematic review

- Diagnostic testing

\section{Key summary points}

- Aim: to describe the range of near-patient tests for UTI in older people, and their predictive properties

- Findings: Near-patient tests for UTI in older people in urgent care settings have been poorly evaluated and have limited predictive properties.

- Message: a wide range of existing and novel tests might be useful in diagnosing UTI, but a more limited number (17) are potentially feasible to apply in the urgent care setting. Clinicians should be vigilant about over-reliance on near-patient diagnostic tests when assessing older people with possible UTI. Further studies are required to define optimal approaches to diagnosing UTI In older people in urgent care settings

\section{Acknowledgements}

We are grateful to the staff and stakeholders who invested their time to discuss this issue.

The authors have no conflicts of interest to declare. 


\section{Abstract ( $n=345$ words)}

Purpose

The aim of this study was to map out the existing knowledge on near-patient tests for urinary tract infections, and use a consensus building approach to identify those which might be worthy of further evaluation in the urgent care context, defined as clinically useful and feasible results available within 4-24 hours.

Methods

A systematic search for reviews describing diagnostic tests for UTI was undertaken in Medline, EMBASE, Cochrane database of systematic reviews and CINAHL Selected reviews were retained according to a priori inclusion and exclusion criteria, then graded for quality using the CASP tool for reviews

A consensus process involving microbiologists and chemical pathologists helped identify which test might conceivably be applied in the urgent care context (e.g. Emergency Department, giving results within 24 hours).

Results

The initial search identified 1079 papers, from which 26 papers describing 35 diagnostic tests were retained for review. The overall quality was limited, with only $7 / 26$ retained papers scoring more than $50 \%$ on the CASP criteria. Reviews on urine dipstick testing reported wide confidence intervals for sensitivity and specificity; several raised concerns about urine dip testing in older people. A number of novel biomarkers were reported upon but appeared not to be helpful in differentiating infection from asymptomatic bacturia. Blood markers such as CRP and Procalcitonin were reported to be helpful in monitoring rather than diagnosing UTI.

The consensus process helped to refine the 35 test down to 17 that might be useful in the urgent care context: Urinalysis (nitrites and leucocytes), Uriscreen catalase test, Lactoferrin, Secretory Immunoglobulin A, Xanthine oxidase, Soluble triggering receptor expressed on myeloid cells, A-1 microglobulin $(\mathrm{a} 1 \mathrm{Mg})$ and a1 Mg/creatinine ratio, Cytokine IL-6, Rapidbac, MALDI-TOF, Electronic Noses, Colorimetric sensor arrays, Electro chemical biosensor, WBC count (blood), C-Reactive Peptide, Erythrocyte Sedimentation Rate.

\section{Conclusions}

A wide range of diagnostic test have been explored to diagnose UTI, but in general have been poorly evaluated or have wide variation in predictive properties. This study identified 17 tests for UTI that seemed to offer some primes and merit further evaluation for diagnosing UTI in older people in urgent care settings. 


\section{Introduction}

Older people are major users of urgent care in Western countries [1, 2], and increasingly in the developing world [3]. Global hospitalisation rates for infection and/or sepsis range between 3-7,000 per 100,000 population with the highest rates being seen in the oldest old, in whom infection is the cause for admission in 10-15\% [4-6]. The diagnosis of infection in older people can present a significant challenge for clinicians, particularly in urgent care settings [7]. A particular confounder is the high frequency of 'Non-Specific Presentations' (NSPs) in older patients i.e. confusion, falls or new immobility [8-13]. Between 50-80\% of NSPs have an acute underlying cause, frequently infection (largely respiratory and urinary tract) [14-16]. A specific consideration in the context of Urinary Tract Infection (UTI) is the frequency of Asymptomatic Bacturia, which should not be treated [17-20], but may be misinterpreted as the cause of the presentation. As many as $25 \%$ to $50 \%$ of older women and $15 \%$ to $40 \%$ of older men in long-term care facilities are bacteriuric [21]; colonisation of urinary catheters is extremely common [22]. Clinicians risk both over and under diagnosis of infection, for example, attributing non-specific signs and symptoms such as increased confusion and loss of function indiscriminately to infection. Over-prescription of antibiotics is linked to the development of antimicrobial resistance as well as unnecessarily exposing patients to potentially harmful adverse events such as $C$. Difficile infection. Under-diagnosis may result in the development of sepsis. Biomarkers such as White Cell Count (WCC) and C-Reactive Protein (CRP), which may have otherwise been useful in the absence of classic signs and symptoms of infection, lack sensitivity and specificity in this population [23-25]. There appears to be a need for a greater research into of the role and advantages of near-patient diagnostic tests for the accurate and timely diagnosis of urinary tract infection in older people [26]. Use of near-patient tests with good sensitivity and specificity described in existing literature may allow for quicker confirmation of UTI diagnosis compared to standard tests for UTI (namely urine dipstick) and help avoid the issues raised above.

The aim of this study was to map out the existing knowledge on near-patient tests for urinary tract infections, and use a consensus building approach to identify those which might be worthy of further evaluation in the urgent care context, defined as clinically useful and feasible results available within 4-24 hours.

\section{Methods}

Mapping review

A systematic search for reviews describing diagnostic tests for UTI in Medline, EMBASE, Cochrane database of systematic reviews and CINAHL was conducted in July 2018 using the following terms:

1. urinary tract infections.mp. or exp Urinary Tract Infections/

2. urinary infection*.mp.

3. uti.mp.

4. exp PYELONEPHRITIS/ or pyelonephritis.mp.

5. 1 or 2 or 3 or 4

6. exp Point-of-Care Testing/

7. bedside test*.tw.

8. poct.tw. 
9. "point of care test*".tw.

10. near patient test*.tw.

11. rapid diagnostic test*.tw.

12. 6 or 7 or 8 or 9 or 10 or 11

13. 5 and 12

14. (review* or systematic or meta analys*).mp. [mp=title, abstract, original title, name of substance word, subject heading word, keyword heading word, protocol supplementary concept word, rare disease supplementary concept word, unique identifier, synonyms]

15. limit 13 to (English language and "review articles")

16. 13 and 14

17. 15 or 16

18. limit 17 to English language

Studies were included for review if they met the inclusion criteria:

- Reviews (literature, systematic or meta-analysis)

- Any near-patient test that could be used to make a diagnosis of UTI within 24 hours

- Not limited by age or setting

- Management guidelines or policies which described UTI diagnosis

Studies were excluded if they met any of the following criteria:

- Studies regarding the prevention of catheter associated UTI

- Studies regarding cytology for possible cancer diagnosis

- Reviews focusing on specific causative organisms

- Coding studies

- Studies where haematuria was the only presenting complaint

- Studies regarding sexually transmitted diseases

- Studies regarding drug or other treatment modalities

- Original papers

- Studies investigating causes or risk factors for UTI e.g. imaging for tract abnormalities

- Editorials or opinion pieces

Titles and abstracts of these reviews were screened by two reviewers (SC and MJ) and consensus was reached for each as to their compliance with the pre-determined inclusion/exclusion criteria. Reviewer agreement for the first two years of potential papers was tested on 27 papers, kappa 0.78 SD $0.19 ; 89 \%$ agreement; disagreements were resolved by discussion. The full text was sought for selected articles or those with ambiguous or unobtainable abstracts. 
The full text of retained articles were read to check eligibility inclusion criteria. The selected papers were read and near-patient tests mentioned within them were identified, data regarding their diagnostic accuracy including Sensitivity, Specificity, Positive/Negative Predictive Value (PPV/NPV), Positive/Negative Likelihood Ratios (PLR/NLR) where included, was extracted by MJ.

A quality assessment of each retained review was carried out by the SC and MJ using the Critical Appraisal Skills Programme (CASP) Checklist for Review Articles. CASP comprises of 10 questions which, when applied to a review and each question is answered with a score, culminate in an overall score out of 14-16 points per article. An average of each reviewer's score was used as the final quality grading.

\section{Selecting tests for further evaluation}

In order to select out tests that could be used in the urgent care setting and with existing technologies (or technology that might be reasonably adapted to the urgent are context - characterised by the need for rapid results ( $<24$ hours) and high volumes), we used a consensus building approach. Table 1 was presented to a team of microbiologists, along with the aims of the study and more detailed descriptions of the test methods. The microbiology team reviewed each of the different tests for their potential use in the urgent care context. Additional discussions were undertaken involving two chemical pathologists to advise upon the blood markers.

\section{Results}

Mapping review

The initial search identified 1079 papers; de-duplicating removed 45 papers, leaving 1034 for review (Figure 1.). 
Figure 1 Study selection diagram

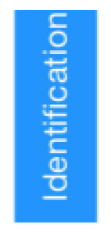

1079 records identified through search of databases
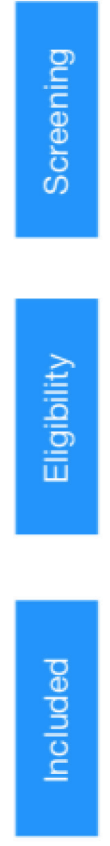

0 additional records identified through other sources

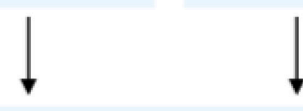

1034 records remained after removal of duplicates

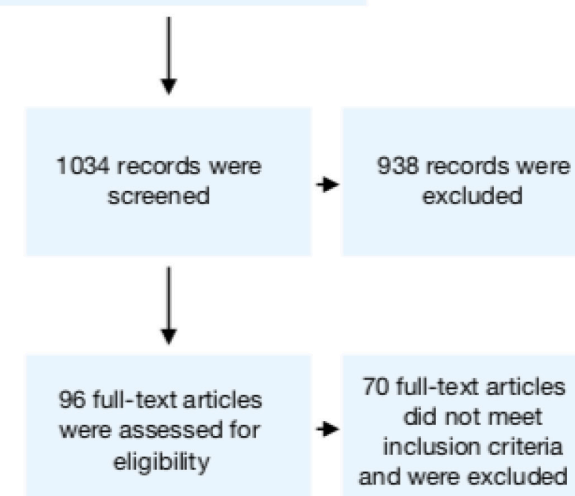

26 studies were included in qualitative synthesis

36 diagnostic tests were identified within the literature and data or statements regarding their diagnostic accuracy were tabulated alongside a description of the test and the paper's CASP score (Table 1). The overall quality was limited, with only $7 / 26$ papers scoring more than $50 \%$ using the CASP criteria. This review did not undertake a meta-analysis as it only reports the summary values from individual reviews rather than the source data; Table 1 indicates the range of predictive values reported. 


\begin{tabular}{|c|c|c|c|c|}
\hline DIAGNOSTIC TEST & BRIEF TEST DESCRIPTION & DIAGNOSTIC ACCURACY & CITATION & $\begin{array}{l}\text { PAPER } \\
\text { QUALITY } \\
\text { GRADING }\end{array}$ \\
\hline \multicolumn{5}{|l|}{ Urinalysis } \\
\hline \multirow[t]{8}{*}{$\begin{array}{l}\text { Standard Urinalysis i.e. urine } \\
\text { dipstick }\end{array}$} & \multirow{12}{*}{$\begin{array}{l}\text { A paper strip with reagents on its surface is } \\
\text { dipped into urine. The reagents change } \\
\text { colour depending on the concentrations of } \\
\text { certain constituents of the urine, including } \\
\text { nitrites and leukocytes. }\end{array}$} & $\begin{array}{l}\text { In neonates: Sn 54-82\%, Sp 92-98\% PPV 45\%, NPV } \\
97 \%\end{array}$ & Baracco [27] & $88 \%$ \\
\hline & & $\begin{array}{l}\text { In older women: Sn } 64-100 \% \text {, Sp 70\% (20-77\%); } \\
\text { PPV } 31-45 \% \text {, NPV } 92-100 \%\end{array}$ & Chu [28] & $9 \%$ \\
\hline & & $\begin{array}{l}\text { 'Urine dipsticks can give false- negative results in the } \\
\text { case of non-nitrite-producing pathogens, such as } \\
\text { Enterococcus and Staphylococcus spp., or in dilute } \\
\text { urine samples' }\end{array}$ & Davenport [29] & $31 \%$ \\
\hline & & $\begin{array}{l}\text { Positive for either nitrites or leukocytes: Sn } 71-90 \% \text {, } \\
\text { Sp } 69-86 \% \\
\text { When nitrites, leukocytes and blood is all negative: } \\
\text { NPV } 76 \% \\
\text { When nitrites and leukocytes or blood are positive: } \\
\text { PPV } 92 \%\end{array}$ & Durojaiye [30] & $13 \%$ \\
\hline & & Sn 45\% (40-61\%), Sp 98\% (96-99\%) & Edefonti [31] & $0 \%$ \\
\hline & & PPV $31-93 \%$, NPV $49-100 \%$ & Eriksen [32] & $69 \%$ \\
\hline & & $\begin{array}{l}\text { 'The combination of the urine LE test with the } \\
\text { urinary nitrite test provides an excellent screen for } \\
\text { establishing the presence of UTI. Most commercially } \\
\text { available urine test strips (dipsticks) allow screening } \\
\text { for both. however, the presence of one or both of } \\
\text { these biomarkers does not help differentiating } \\
\text { between UTI and asymptomatic bacteriuria' }\end{array}$ & Masajtis [33] & $63 \%$ \\
\hline & & $\begin{array}{l}\text { Positive nitrites or leukocytes: Sn } 73 \%(59-83 \%), \mathrm{Sp} \\
89 \%(79-94 \%)\end{array}$ & $\begin{array}{l}\text { Rogozinska } \\
{[34]}\end{array}$ & $88 \%$ \\
\hline \multirow[t]{4}{*}{ Nitrites } & & $\begin{array}{l}\text { Nitrite +/- LE: Sn } 75 \%, \text { Sp } 82 \% \text {; PPV } 79 \% \text {, NPV } \\
75 \% \\
\text { 'Although the presence of nitrites or LE are both } \\
\text { useful, nitrite is more useful as a diagnostic indicator } \\
\text { of UTI pooled diagnostic odds ratio of } 11.3 \text { ' }\end{array}$ & Chu [28] & $9 \%$ \\
\hline & & $\begin{array}{l}\text { Sn } 48 \% \text { 'Urine dipsticks can give false-negative } \\
\text { results in the case of non-nitrite-producing pathogens, } \\
\text { such as Enterococcus and Staphyloccocus, or in } \\
\text { dilute urine samples.' }\end{array}$ & Davenport [29] & $31 \%$ \\
\hline & & Sn $44-64 \%$, Sp 96-99\% & Durojaiye [30] & $13 \%$ \\
\hline & & Sn 49\% (41-57\%), Sp 98\% (96-99\%) & Edefonti [31] & $0 \%$ \\
\hline
\end{tabular}




\begin{tabular}{|c|c|c|c|c|}
\hline & & Sn $54-83 \%$, Sp 48-100\% & Eriksen [32] & $69 \%$ \\
\hline & & Sn $36-57 \%$, Sp 75-95\% & $\begin{array}{l}\text { Masajtis- } \\
\text { Zagajewskain } \\
{[33]}\end{array}$ & $63 \%$ \\
\hline & & Sn $44 \%$, Sp 97\% & Matulay [35] & $19 \%$ \\
\hline & & Sn 55\% (42-67\%), Sp 99\% (98-99\%) & $\begin{array}{l}\text { Rogozinska } \\
{[34]}\end{array}$ & $88 \%$ \\
\hline $\begin{array}{l}\text { Leukocyt- } \\
\text { esterase }\end{array}$ & & $\begin{array}{l}\text { 'Because leucocyturia mainly reflects inflammation } \\
\text { at the urinary tract level, it should not be taken into } \\
\text { account to confirm infection, especially in this } \\
\text { neurological population. However, when leucocyturia } \\
\text { is not found on urine analysis, another diagnosis } \\
\text { other than urinary tract infection should be } \\
\text { considered.' }\end{array}$ & Biardeau [36] & $13 \%$ \\
\hline & & Sn $61-84 \%$, Sp 74-90\% & Durojaiye [30] & $13 \%$ \\
\hline & & Sn $79 \%(73-84 \%)$, Sp $75-95 \%$ & Edefonti [31] & $0 \%$ \\
\hline & & Sn $69-98 \%$, Sp 26-81\% & Eriksen [32] & $69 \%$ \\
\hline & & Sn $36-57 \%$, Sp 9-83\% & $\begin{array}{l}\text { Masajtis- } \\
\text { Zagajewskain } \\
{[33]}\end{array}$ & $63 \%$ \\
\hline & & Sn $84 \%$, Sp $59 \%$ & Matulay [35] & $19 \%$ \\
\hline Enhanced Urinalysis & $\begin{array}{l}\text { Uncentrifuged urine sample undergoes Gram } \\
\text { staining and cell counting by } \\
\text { haemocytometer. }\end{array}$ & In neonates: Sn 82-96\%, Sp 94\%; NPV 99.7 & Baracco [27] & $0 \%$ \\
\hline Griess test for nitrites & $\begin{array}{l}\text { The Griess test uses a reagent of sulphanilic } \\
\text { acid, acetic acid and } \propto \text {-naphthylamine. } \\
\text { Nitrites are present if the solution turns } \\
\text { pink/red. }\end{array}$ & $\begin{array}{l}\text { Sn } 65 \%(50-78 \%), \text { Sp 99\% }(98-100 \%) \text {; likelihood } \\
\text { ratio } 57(95 \% \text { CI } 13-255)\end{array}$ & $\begin{array}{l}\text { Rogozinska } \\
{[34]}\end{array}$ & $88 \%$ \\
\hline Clorhexidine reaction & $\begin{array}{l}\text { Clorhexidine is added to the urine sample. If } \\
\text { the sample becomes cloudy after the solution } \\
\text { is shaken then the test is positive for } \\
\text { bacteria. }\end{array}$ & Sn $100 \%(65-100 \%)$, Sp 54\% (46-62\%) & $\begin{array}{l}\text { Rogozinska } \\
{[34]}\end{array}$ & $88 \%$ \\
\hline Uriscreen catalase test & $\begin{array}{l}\text { Uriscreen reagent is added to the sample } \\
\text { and, if positive for bacterial enzymes, foam } \\
\text { is produced. The quantity of foam is directly } \\
\text { proportional to the number of bacteria } \\
\text { present. }\end{array}$ & Sn 65\% (50-78\%), Sp 99\% (98-100\%) & $\begin{array}{l}\text { Rogozinska } \\
{[34]}\end{array}$ & $88 \%$ \\
\hline Novel Biomarkers & & & & \\
\hline $\begin{array}{l}\text { Elastase alpha (1)-proteinase } \\
\text { inhibitor }\end{array}$ & Immunoassay & $\begin{array}{l}\text { 'Elevated levels of E-alpha(1)-PI in urine seem to be } \\
\text { a useful tool for the diagnosis of UTI in neonates.' }\end{array}$ & $\begin{array}{l}\text { Masajtis- } \\
\text { Zagajewskain } \\
\text { [33] }\end{array}$ & $63 \%$ \\
\hline
\end{tabular}




\begin{tabular}{|c|c|c|c|c|}
\hline Lactoferrin & $\begin{array}{l}\text { Lactoferrin levels can be detected using } \\
\text { electrochemical immunosensors or } \\
\text { immunochromatography test strips. }\end{array}$ & $\begin{array}{l}\text { 'Urinary LF is a sensitive marker and provides a } \\
\text { useful tool for the simple and rapid diagnosis of UTI' }\end{array}$ & $\begin{array}{l}\text { Masajtis- } \\
\text { Zagajewskain } \\
{[33]}\end{array}$ & $63 \%$ \\
\hline Secretory Immunoglobulin A & $\begin{array}{l}\text { sIgA levels are measured using specific } \\
\text { enzyme-linked immunosorbent assay } \\
\text { (ELIZA). }\end{array}$ & $\begin{array}{l}\text { 'Presence of sIgA correlated with UTI in children and } \\
\text { adults and seems to be directed to the infective agent } \\
\text { and can also be used to identify the type of infection.' }\end{array}$ & $\begin{array}{l}\text { Masajtis- } \\
\text { Zagajewskain } \\
{[33]}\end{array}$ & $63 \%$ \\
\hline $\begin{array}{l}\text { Heparin-Binding Protein } \\
\text { (HBP) }\end{array}$ & $\begin{array}{l}\text { HBP levels are measured using specific } \\
\text { ELISA. }\end{array}$ & $\begin{array}{l}\text { Sn } 89 \%, \text { Sp } 90 \% \\
\text { 'U-HBP is the best diagnostic marker for UTI and } \\
\text { could also discriminate between cystitis and } \\
\text { pyelonephritis. U-HBP can be helpful guidance in the } \\
\text { management of children with suspected UTI.' }\end{array}$ & $\begin{array}{l}\text { Masajtis- } \\
\text { Zagajewskain } \\
{[33]}\end{array}$ & $63 \%$ \\
\hline Xanthine oxidase & Urine samples undergo assay for $\mathrm{XO}$ activity & $\begin{array}{l}\text { Sn } 100 \% \text {, Sp } 100 \% \\
\text { 'This marker will be useful in early diagnosis of UTI' } \\
\text { 'The study demonstrates that significantly increased } \\
\text { activity XO is present only if the urine contains } \\
\text { bacteria in amount }>10^{5} \text { per ml. Moreover, the } \\
\text { measurement of urine XO }\end{array}$ & $\begin{array}{l}\text { Masajtis- } \\
\text { Zagajewskain } \\
{[33]}\end{array}$ & $63 \%$ \\
\hline $\begin{array}{l}\text { Soluble triggering receptor } \\
\text { expressed on myeloid cells }\end{array}$ & $\begin{array}{l}\text { sTREM levels are measured using specific } \\
\text { ELISA. }\end{array}$ & $\begin{array}{l}\text { 'This marker is a reliable biological marker for } \\
\text { bacterial infection but may not be sufficient for } \\
\text { detection of urinary tract infection due to its low Sn.' }\end{array}$ & $\begin{array}{l}\text { Masajtis- } \\
\text { Zagajewskain } \\
{[33]}\end{array}$ & $63 \%$ \\
\hline A-1 microglobulin & $\begin{array}{l}\text { Specific latex immunoassay technique } \\
\text { available in commercial test kits. }\end{array}$ & $\begin{array}{l}\text { 'Non-invasive and cost effective strategy with } \\
\text { diagnostic capability for urinary tract disorders such } \\
\text { as early recognition damages during pyelonephritis.' }\end{array}$ & $\begin{array}{l}\text { Masajtis- } \\
\text { Zagajewskain } \\
{[33]}\end{array}$ & $63 \%$ \\
\hline Cytokine IL-6 & Detected by specific ELISA. & $\begin{array}{l}\text { 'Neither increased concentration of interleukin- } 6 \text { in } \\
\text { the urine or the use of urine dipsticks is suitable as an } \\
\text { indicator of unspecific symptoms and bacteria in the } \\
\text { urine' }\end{array}$ & Eriksen [32] & $69 \%$ \\
\hline RNA Biosignatures & $\begin{array}{l}\text { RNA extraction and genomic analyses } \\
\text { resulting in a microarray. }\end{array}$ & $\begin{array}{l}\text { Sn } 87 \%, \text { Sp } 89 \% \\
\text { with a Sn ranging between } 90-100 \% \text { and a Sp of } \\
95.8-956 \% \text { (below) } \\
\text { 2-transcript RNA signature has the potential to } \\
\text { discriminate between bacterial and viral infections: } \\
\text { Sn } 90-100 \% \text {, Sp } 95.8-96 \%\end{array}$ & Dorney [37] & $44 \%$ \\
\hline 3 Protein Signature & $\begin{array}{l}\text { CRP as per standard lab-specific procedure. } \\
\text { Tumour necrosis factor related apoptosis } \\
\text { inducing ligand (TRAIL) and INF-Gamma- } \\
\text { Induced Protein } 10 \text { detected by specific } \\
\text { ELISA. }\end{array}$ & $\begin{array}{l}\text { ' } 3 \text { protein signature (tumour necrosis factor related } \\
\text { apoptosis inducing ligand, IFN-g-induced protein-10, } \\
\text { and CRP) that was superior to any combination of } \\
\text { routinely used clinical and laboratory parameters at } \\
\text { distinguishing between infectious and non-infectious } \\
\text { presentations as well as between bacterial and viral } \\
\text { infections.' }\end{array}$ & Dorney [37] & $44 \%$ \\
\hline
\end{tabular}




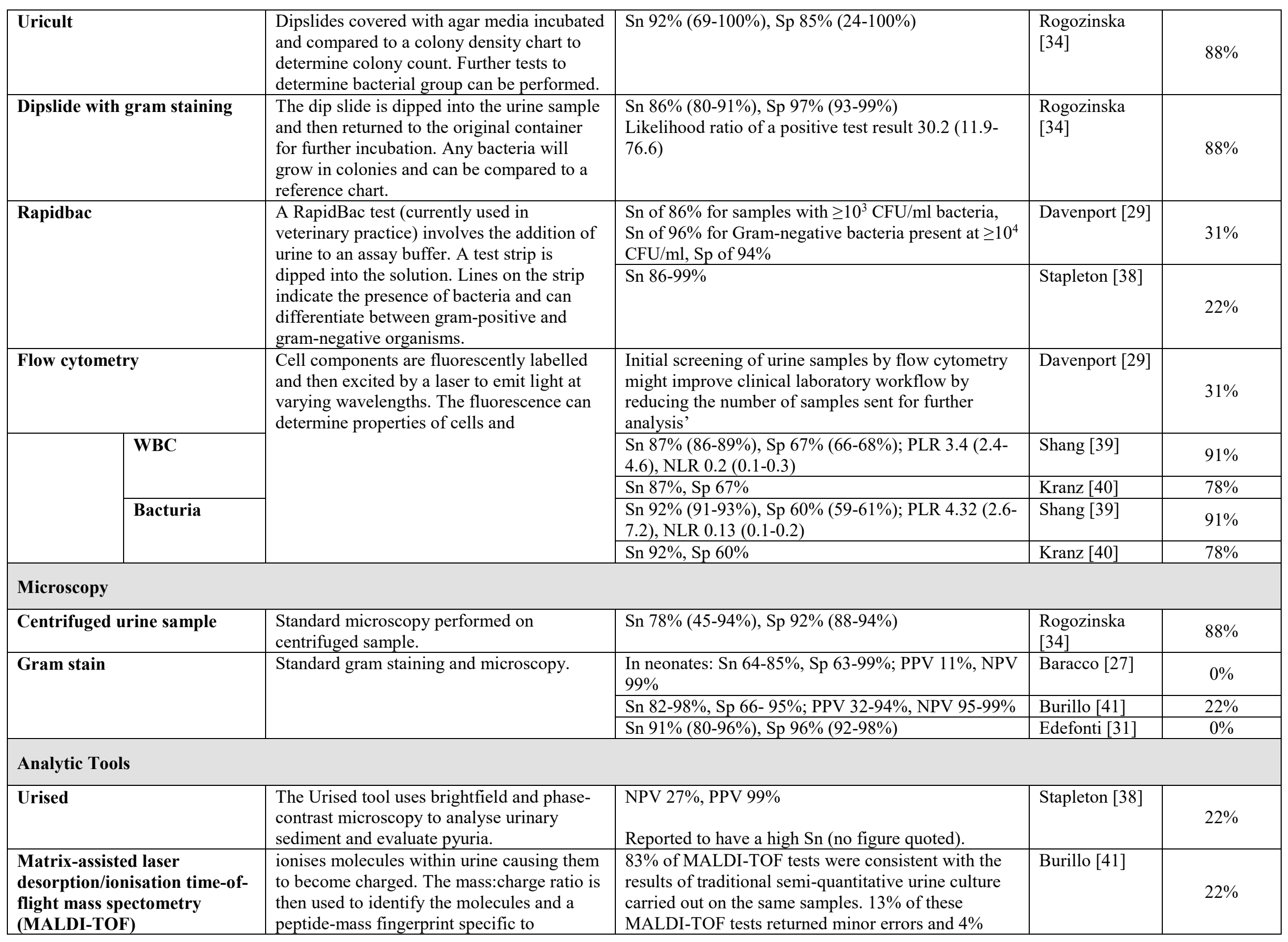


organisms generated. These are compared against a database of existing reference spectra to determine the organism.

\begin{tabular}{|l|l|c|}
\hline $\begin{array}{l}\text { returned significant errors that could be clinically } \\
\text { misleading. }\end{array}$ & & \\
\hline Sn $67-86 \%$ & Davenport [29] & $31 \%$ \\
\hline Sn $67 \%$, Sp $100 \%$ & DeMarco [42] & $28 \%$ \\
\hline
\end{tabular}

Biosensors for Volatile Organic Compounds: miniaturised analytic tools with a fast response time

\begin{tabular}{|c|c|c|c|c|}
\hline Electronic Noses & $\begin{array}{l}\text { Electronic noses are hand-held devices that } \\
\text { mimic the olfactory system and detect a } \\
\text { specific signature of volatile organic } \\
\text { compounds (VOCs) produced by bacteria. } \\
\text { This can be carried out within } 15 \text { minutes. }\end{array}$ & Sn $95 \%$, Sp $97 \%$ & Davenport [29] & $31 \%$ \\
\hline Colorimetric arrays & $\begin{array}{l}\text { A thin film printed with variety of dyes that } \\
\text { change colour on the binding of compounds } \\
\text { such as amines, fatty acids, alcohols, } \\
\text { sulfides, and aldehydes. An agar-filled petri } \\
\text { dish is inoculated with the sample and the } \\
\text { array is placed the in a petri dish lid; as the } \\
\text { bacteria grow, the VOCs produced cause a } \\
\text { distinctive pattern of colour changes that can } \\
\text { be read by scanner or smartphone camera for } \\
\text { analysis. }\end{array}$ & Sn $91 \%$, Sp 99\% & Davenport [29] & $31 \%$ \\
\hline Electrochemical biosensor & $\begin{array}{l}\text { Electochemical biosensors involve sandwich } \\
\text { hybridisation of } 16 \mathrm{~S} \text { rRNA with a } \\
\text { recognition element (a capture DNA } \\
\text { oligonucleotide) and detection of these } \\
\text { complexes by a DNA proble. Amperometric } \\
\text { measurement of ions present in urine based } \\
\text { on the electric current they produce allows } \\
\text { for quantification of detected uropathogens. } \\
\text { A panel of probes performing this assay can } \\
\text { detect a wide variety of pathogens within } \\
\text { one hour. }\end{array}$ & $\begin{array}{l}\text { Sn } 92 \%, \mathrm{Sp} 97 \% \\
\text { '..has great potential for integration in point-of-care } \\
\text { diagnostics, as this assay can combine genotypic } \\
\text { pathogen identification with phenotypic AST for } \\
\text { comprehensive diagnosis.' }\end{array}$ & Davenport [29] & $31 \%$ \\
\hline \multicolumn{5}{|l|}{ Genome Sequencing Tools } \\
\hline $\begin{array}{l}\text { Fluorescence in Situ } \\
\text { Hybridisation (FISH) }\end{array}$ & $\begin{array}{l}\text { FISH assays detect fluorescently labelled } \\
\text { nucleic acid probes hybridised to } \\
\text { complementary targets using microscopy. }\end{array}$ & Sn and $\mathrm{Sp}>96 \%$ & Davenport [29] & $31 \%$ \\
\hline Multiplex PCR & $\begin{array}{l}\text { Nucleic acid amplification by polymerase } \\
\text { chain reaction. Real time PCR such as } \\
\text { SeptiFast has a multiplex panel which }\end{array}$ & $\begin{array}{l}\text { Concordance of SeptiFast with traditional culture: } \\
\text { gram-positive bacteria } 90 \% \text {, gram-negative bacteria } \\
97 \% \text {, fungi } 97 \% \text {; Sn } 82 \% \text {, Sp } 60 \%\end{array}$ & Davenport [29] & $31 \%$ \\
\hline
\end{tabular}




\begin{tabular}{|c|c|c|c|c|}
\hline & $\begin{array}{l}\text { targets gram- positive and negative bacteria } \\
\text { as well as fungi. }\end{array}$ & $\begin{array}{l}\text { 'SeptiFast identification was available at least } 43 \\
\text { hours before culture results' (but cannot differentiate } \\
\text { between clinically significant bacterial loads and } \\
\text { contamination) } \\
\text { Sn } 82 \%, \text { Sp } 60 \%\end{array}$ & & \\
\hline \multicolumn{5}{|l|}{ Blood Tests } \\
\hline Blood Cultures & Standard lab-specific procedure. & $\begin{array}{l}\text { It is not practicable to use blood cultures as a rapid } \\
\text { diagnostic tool. } \\
\text { Should be performed for all patient showing red flag } \\
\text { signs of sepsis. Although positive blood culture } \\
\text { findings will not affect the length of antibiotic } \\
\text { therapy prescribed, they could provide evidence for a } \\
\text { urinary tract infection and guide antibiotic therapy-- } \\
\text { by identifying a specific bacteria.' }\end{array}$ & Biardeau [36] & $13 \%$ \\
\hline WBC count & Standard lab-specific procedure. & 'Will only be of interest to monitor infection.' & Biardeau [36] & $13 \%$ \\
\hline \multicolumn{5}{|c|}{ Inflammatory markers in Blood } \\
\hline \multirow[t]{4}{*}{ CRP } & \multirow[t]{4}{*}{ Standard lab-specific procedure. } & $\begin{array}{l}\text { In neonates: } \mathrm{Sn} 59 \% \text {, Sp } 90 \% \text {; when CRP greater } \\
\text { than } 20 \text { was combined with pyuria on enhanced } \\
\text { urinalysis, the Sp increased to } 98 \% \text {. }\end{array}$ & Baracco [27] & $0 \%$ \\
\hline & & $\begin{array}{l}\text { 'C-reactive protein measurement will be of interest } \\
\text { only to monitor infection.' }\end{array}$ & Biardeau [36] & $13 \%$ \\
\hline & & Serum CRP $>8.7 \mathrm{mg} / \mathrm{dl}: \mathrm{Sn} 93 \%, \mathrm{Sp} 86 \%$ & Burillo & $22 \%$ \\
\hline & & $\begin{array}{l}\text { CRP (20mg/Ml): Sn 94\% (85-97\%), Sp 39\% (23- } \\
58 \%)\end{array}$ & Shaikh [43] & $94 \%$ \\
\hline \multirow[t]{2}{*}{ ESR } & \multirow[t]{2}{*}{ Standard lab-specific procedure. } & $\begin{array}{l}\text { In neonates: } \mathrm{Sn} 70 \%, \mathrm{Sp} 78 \% \text {; Sp of ESR greater } \\
\text { than } 30 \text { increased to } 97 \% \text { when combined with pyuria } \\
\text { on enhanced urinalysis. }\end{array}$ & Baracco [27] & $0 \%$ \\
\hline & & ESR (30mm/h): Sn 87\% (77-93\%), Sp 48\% (32-64\%) & Shaikh [43] & $94 \%$ \\
\hline \multirow[t]{4}{*}{ Procalcitonin } & \multirow[t]{4}{*}{ Standard lab-specific procedure. } & $\begin{array}{l}\text { '...found to be both sensitive and specific for acute } \\
\text { pyelonephritis.' }\end{array}$ & Baracco [27] & $0 \%$ \\
\hline & & $\begin{array}{l}\text { Procalcitonin (cut-off 0.25ng/Ml): Sn 95\% (89-98\%), } \\
\text { Sp 50\% (46-55\%) }\end{array}$ & Dreger [44] & $44 \%$ \\
\hline & & Sn 58-94\%, Sp 36-94\% & $\begin{array}{l}\text { Masajtis- } \\
\text { Zagajewskain } \\
\text { [33] }\end{array}$ & $63 \%$ \\
\hline & & $\begin{array}{l}\text { Procalcitonin (cut-off 0.5ng/Ml): Sn 86\% (71-93\%), } \\
\text { Sp 74\% (55-87\%) }\end{array}$ & Shaikh [43] & $94 \%$ \\
\hline
\end{tabular}


A wide range of diagnostic tests for the diagnosis of UTI have been reported in the literature. The higher quality papers (CASP score $>60 \%$ - Baracco [27], Eriksen [32], Masajtis-Zagajewskain [33], Rogozinska [34], Shang [39]) generally highlighted better negative predictive value for urinalysis when nitrates and leucocytes were both absent but recognised that positive urine dip tests do not overcome the issue of asymptomatic bacturia. All reported wide confidence intervals for sensitivity and specificity. Many reviews concluded that urine dipsticks were not suitable for the diagnosis of UTI in older people (Eriksen [32], Davenport [29], Masajtis-Zagajewskain [33], Biardeau [36]).

Shang [39] suggested that flow cytometry testing for leucocytes and nitrites might reduce the need for laboratories to process quite so many specimens, but did not help achieve an early diagnosis. Masajtis-Zagajewskain [33] reported on a number of novel biomarkers, some of which appeared promising (e.g. Heparin-Binding Protein) and Eriksen [32] on cytokine IL-6 but none of these appeared to be able to distinguish between infection and asymptomatic bacturia.

Biosensors for volatile organic compounds as described by Davenport [29] showed high sensitivity and specificity although it is not yet clear whether they have the capability to differentiate between asymptomatic bacturia and UTI. Baracco [27], Biardeau [36], Burillo [41] and Shaikh [43] all suggested that CRP might be helpful for monitoring treatment response, but not diagnosing UTI. Procalcitonin was reported in five reviews, with the more robust reviews (Masajtis-Zagajewskain [33], Shaikh [43]) highlighting wide confidence intervals.

Overall, no one marker came out as sufficiently sensitive and specific, with robust likelihood ratios to differentiate between genuine UTI and asymptomatic bacturia.

\section{Selecting tests for further evaluation}

An initial presentation of Table 2 and the study aims was made to a group of six clinical microbiologists at the Leicester Royal Infirmary in December 2018. The group acknowledged the clinical conundrum and the limitations of current diagnostic approaches. Two consultant microbiologists agreed to review the tests for use in the urgent care context; the results of their deliberations and those of the chemical pathologists are shown in Table 2. 
Table 2 Selection process for near-patient test for UTI derived from the mapping review

\begin{tabular}{|c|c|c|}
\hline Diagnostic Test & Comments & Retain? \\
\hline Urinalysis & Quick, simple and easy to use, but concerns about validity & Yes \\
\hline Griess test for nitrites & No added benefit over standard urinalysis & No \\
\hline Chlorhexidine reaction & Not practical in the urgent care setting & No \\
\hline Uriscreen catalase test & $\begin{array}{l}\text { Could be useful; takes about } 10 \text { minutes to complete. May miss catalase } \\
\text { negative organisms }\end{array}$ & Yes \\
\hline \multicolumn{3}{|l|}{ Novel Biomarkers } \\
\hline Elastase alpha (1)-proteinase & Not possible & No \\
\hline Lactoferrin & Potentially helpful & Yes \\
\hline Secretory Immunoglobulin A & Potentially helpful & Yes \\
\hline Heparin-Binding Protein & Not practical in the urgent care setting & No \\
\hline Xanthine oxidase & Potentially helpful & Yes \\
\hline $\begin{array}{l}\text { Soluble triggering receptor expressed on } \\
\text { myeloid cells }\end{array}$ & Potentially helpful & Yes \\
\hline $\begin{array}{l}\text { A-1 microglobulin }(\mathrm{a} 1 \mathrm{Mg}) \text { and } \\
\text { a1Mg/creatinine ratio }\end{array}$ & Possible & Yes \\
\hline Cytokine IL-6 & Potentially helpful & Yes \\
\hline RNA Biosignatures & Not practical and does not circumvent asymptomatic bacturia conundrum & No \\
\hline 3 Protein Signature & Not possible & No \\
\hline Uricult & Take more than 24 hours & No \\
\hline $\begin{array}{l}\text { Dipslide with gram staining on } \\
\text { uncentrifuged urine }\end{array}$ & Take more than 24 hours & No \\
\hline Rapidbac & Not currently licensed for human use but potentially helpful and quick & Yes \\
\hline Flow cytometry & Primarily for use in microbiology laboratories & No \\
\hline \multicolumn{3}{|l|}{ Microscopy } \\
\hline Centrifuged urine sample & Not practical in the urgent care setting & No \\
\hline Gram stain & Not practical in the urgent care setting & No \\
\hline Urine Culture (48 hours) & Not practical in the urgent care setting & No \\
\hline \multicolumn{3}{|l|}{ Analytic Tools } \\
\hline Urised & Not practicable and offers little over urine dipstick testing & No \\
\hline MALDI-TOF & Potentially useful and newer devices can obtain results in less than six hours & Yes \\
\hline \multicolumn{3}{|l|}{ Biosensors for Volatile Organic Compounds } \\
\hline Electronic Noses & Potentially helpful & Yes \\
\hline Colorimetric sensor arrays & Potentially helpful & Yes \\
\hline
\end{tabular}




\begin{tabular}{|l|l|l|}
\hline Electro chemical biosensor & Potentially helpful & \multicolumn{2}{l|}{ Yes } \\
\hline \multicolumn{2}{|l|}{ Genome Sequencing Tools } & \multicolumn{2}{l|}{} & \multicolumn{2}{l|}{} \\
\hline FISH & Not practicable and offers little over MALDI-TOF & No \\
\hline Multiplex PCR & Not practicable and offers little over MALDI-TOF & \multicolumn{2}{l|}{} \\
\hline Blood tests & & No \\
\hline Blood Cultures & Takes more than 24 hours (but needed as reference test) & Yes \\
\hline WBC count & Potentially helpful & Yes \\
\hline Inflammatory markers & Potentially helpful & Yes \\
\hline CRP & Potentially helpful & Yes \\
\hline ESR & Potentially helpful & Yes \\
\hline Procalcitonin & Potentially helpful & \\
\hline
\end{tabular}

\section{Discussion}

The aim of this study was to identify near-patient diagnostic tests for UTI described in existing review literature, which may have the potential to improve diagnosis of UTI in the urgent care context. The review identified a range of these tests and attempted to gain an idea of their diagnostic accuracy. Following the review and consensus exercise the following 17 diagnostic tests (reported range of predictive properties)) were considered potentially useful to take forwards for further evaluation:

- Urinalysis (nitrites and leucocytes): sensitivity $59-83 \%$, specificity $79-94 \%$

- Uriscreen catalase test: sensitivity 50-78\%, specificity $98-100 \%$

- Lactoferrin: no data

- Secretory Immunoglobulin A: no data

- Xanthine oxidase: sensitivity $100 \%$, specificity $100 \%$

- Soluble triggering receptor expressed on myeloid cells: no data

- A-1 microglobulin (a1Mg) and a1Mg/creatinine ratio

- Cytokine IL-6: specific to UTI

- Rapidbac: sensitivity $96 \%$, specificity $94 \%$

- MALDI-TOF: sensitivity $67 \%$, specificity $100 \%$

- Electronic Noses: sensitivity 95\%, specificity 97\%

- Colorimetric sensor arrays: sensitivity $91 \%$, specificity $99 \%$

- Electro chemical biosensor: sensitivity $92 \%$, specificity $97 \%$

- WBC count (blood): no data specific to UTI

- CRP: sensitivity $85-97 \%$, specificity $23-58 \%$

- ESR: sensitivity $77-93 \%$, specificity $32-64 \%$ 
- Prolactin: $0.25 \mathrm{ng} / \mathrm{mL}$ - sensitivity $89-98 \%$, specificity $46-55 \% ; 0.5 \mathrm{ng} / \mathrm{mL}$ - sensitivity $71-93 \%$, specificity $55-87 \%$

The strengths of this mapping review are a systematic and broad search for potentially useful near-patient diagnostic tests which, combined with a feasibility consensus exercise with relevant stakeholders, produced a succinct list of diagnostic tests with the potential for further study, focused on rapid diagnosis in the urgent care context. This consensus building process ensured that the tests identified by the search were practicable and grounded in clinical reality. No formal voting process was used as the goal was not to rank tests but to determine if they could be considered for evaluation in a future study of older people with possible urinary tract infection.

A review of reviews, by definition only provides a high-level overview of tests used, along with brief summaries of test characteristics and performance in specific settings; however, all of the individual reviews are referenced here for reading. The review captured all tests that have been reported for the diagnosis of UTI, but did not consider their practicality and utility in an urgent care context. A further weakness is the lack of detail on emerging tests, such as those that have been reported, or that appear in the grey literature, which may be relevant, but are not yet represented in reviews. Although the consensus discussion did not identify any additional diagnostic tests a more definitive review would require a forward search to ensure no new techniques have been omitted.

In our interview study of clinicians who manage patients with possible UTIs in urgent care settings we identified that sample collection technique was a significant factor in ensuring the timely and accurate diagnosis of UTI, as well as the test characteristics [7]. The study revealed widespread misunderstanding of sample collection techniques and highlighted a number of practical challenges on obtaining samples from older people with complex needs such as immobility or acute or chronic confusion. Urinary catheters can facilitate easy sample collection but introduce the risk of detecting an asymptomatic bacteria related to colonisation of the catheter as opposed to infection of the urinary tract. A review to seek out additional evidence regarding sample collection and analysis such as novel sample collection techniques that are able to automatically collect and analyse samples (such as sanitary toilets [45]) would be helpful.

Recent Infectious Diseases Society of America guidance [26] highlights the complexity and the need for better evidence on diagnosing and managing UTI in older people. This mapping review identified 17 clinically feasible, near-patient diagnostic tests with the potential to improve diagnosis of UTI in older patients in an urgent care setting. The process of diagnosing UTIs in this demographic and setting may significantly benefit from the introduction of one, or a combination of, these tests into routine practice. To establish which (if any) of these tests would be best suited to this task, further cohort studies investigating the diagnostic accuracy and practical acceptability (to clinicians, laboratory staff and patients) of them should be conducted. This review and consensus building process goes some way to identifying tests for UTI in older people that merit further exploration in the urgent care setting. 


\section{References}

1. Rechel B, Grundy E, Robine J-M, Cylus J, Mackenbach JP, Knai C et al. Ageing in the European Union. The Lancet. 2013;381(9874):1312-22. doi:https://doi.org/10.1016/S0140-6736(12)62087-X.

2. Spillman BC, Lubitz J. The Effect of Longevity on Spending for Acute and Long-Term Care. New England Journal of Medicine. 2000;342(19):1409-15. doi:10.1056/nejm200005113421906.

3. World Health Organization. World report on Ageing and Health. Luxembourg2015.

4. Knoop ST, Skrede S, Langeland N, Flaatten HK. Epidemiology and impact on all-cause mortality of sepsis in Norwegian hospitals: A national retrospective study. PLoS ONE [Electronic Resource]. 2017;12(11):e0187990.

5. Goto T, Yoshida K, Tsugawa Y, Camargo CA, Jr., Hasegawa K. Infectious Disease-Related Emergency

Department Visits of Elderly Adults in the United States, 2011-2012. Journal of the American Geriatrics Society. 2016;64(1):31-6.

6. Walkey AJ, Lagu T, Lindenauer PK. Trends in sepsis and infection sources in the United States. A populationbased study. Annals of the American Thoracic Society. 2015;12(2):216-20.

7. O’Kelly K, Phelps K, Regen EL, Carvalho F, Kondova D, Mitchell V et al. Why are we misdiagnosing urinary tract infection in older patients? A qualitative inquiry and roadmap for staff behaviour change in the emergency department. European Geriatric Medicine. 2019:1-9. doi:10.1007/s41999-019-00191-3.

8. Vanpee D, Swine C, Vandenbossche P, Gillet J. Epidemiological profile of geriatric patients admitted to the emergency department of a university hospital localized in a rural area. European Journal of Emergency Medicine. 2001;8(4):301-4.

9. Nemec M, Koller M, Nickel C. Patients presenting to the emergency department with non-specific complaints: the Basel Non-specific Complaints (BANC) study. Acad Emerg Med. 2010 17(3):284-92. doi:10.1111/j.15532712.2009.00658.x.

10. Limpawattana P, Phungoen P, Mitsungnern T, Laosuangkoon W, Tansangworn N. Atypical presentations of older adults at the emergency department and associated factors. Archives of Gerontology \& Geriatrics. 2016;62:97102.

11. Eriksson I, Gustafson Y, Fagerstrom L, Olofsson B. Urinary tract infection in very old women is associated with delirium. International Psychogeriatrics. 2011;23(3):496-502.

12. Manepalli J, Grossberg GT, Mueller C. Prevalence of delirium and urinary tract infection in a psychogeriatric unit. Journal of Geriatric Psychiatry \& Neurology. 1990;3(4):198-202.

13. Wojszel ZB, Toczyńska-Silkiewicz M. Urinary tract infections in a geriatric sub-acute ward-health correlates and atypical presentations. European Geriatric Medicine. 2018;9(5):659-67. doi:10.1007/s41999-018-0099-2. 14. Rutschmann OT, Chevalley T, Zumwald C, Luthy C, Vermeulen B, Sarasin FP. Pitfalls in the emergency department triage of frail elderly patients without specific complaints. Swiss Med Wkly. 2005;135(9-10):145-50. 15. Elmståhl S, Wahlfrid C. Increased medical attention needed for frail elderly initially admitted to the emergency department for lack of community support. Aging (Milan, Italy). 1999;11(1):56-60.

16. Nemec M, Koller MT, Nickel CH, Maile S, Winterhalder C, Karrer C et al. Patients Presenting to the Emergency Department With Non-specific Complaints: The Basel Non-specific Complaints (BANC) Study. Academic Emergency Medicine. 2010;17(3):284-92.

17. Nicolle LE, Bradley S, Colgan R, Rice JC, Schaeffer A, Hooton TM. Infectious diseases society of America guidelines for the diagnosis and treatment of asymptomatic bacteriuria in adults. Clinical Infectious Diseases. 2005;40(5):643-54. doi:10.1086/427507.

18. European Urinalysis Guidelines. Scandinavian Journal of Clinical and Laboratory Investigation, Supplement. 2000;60(231):1-96.

19. Scottish Intercollegiate Guidelines Network. Management of suspected bacterial urinary tract infection in adults. 2012.

20. European Centre for Disease Prevention and Control. Proposals for EU guidelines on the prudent use of antimicrobials in humans. . Stockholm: ECDC; 2017.

21. Lin K, Fajardo K. Screening for asymptomatic bacteriuria in adults: evidence for the U.S. Preventive Services Task Force reaffirmation recommendation statement. Ann Intern Med. 2008;149(1):W20-4.

22. Meddings J, Rogers MAM, Krein SL, Fakih MG, Olmsted RN, Saint S. Reducing unnecessary urinary catheter use and other strategies to prevent catheter-associated urinary tract infection: an integrative review. BMJ Quality \& Safety. 2013. doi:10.1136/bmjqs-2012-001774.

23. Simon L, Gauvin F, Amre DK, Saint-Louis P, Lacroix J. Serum procalcitonin and C-reactive protein levels as markers of bacterial infection: a systematic review and meta-analysis. Clinical Infectious Diseases. 2004;39(2):20617. 
24. Takwoingi Y, Quinn TJ. Review of Diagnostic Test Accuracy (DTA) studies in older people. Age and Ageing. 2018;47(3):349-55. doi:10.1093/ageing/afy023.

25. Sundvall PD, Elm M, Ulleryd P, Molstad S, Rodhe N, Jonsson L et al. Interleukin-6 concentrations in the urine and dipstick analyses were related to bacteriuria but not symptoms in the elderly: a cross sectional study of 421 nursing home residents. BMC Geriatrics. 2014;14:88.

26. Nicolle LE, Gupta K, Bradley SF, Colgan R, DeMuri GP, Drekonja D et al. Clinical Practice Guideline for the Management of Asymptomatic Bacteriuria: 2019 Update by the Infectious Diseases Society of Americaa. 2019. doi:10.1093/cid/ciy1121.

27. Baracco R, Mattoo TK. Diagnosis and management of urinary tract infection and vesicoureteral reflux in the neonate. Clinics in Perinatology. 2014;41(3):633-42. doi:10.1016/j.clp.2014.05.011.

28. Chu CM, Lowder JL. Diagnosis and treatment of urinary tract infections across age groups. American journal of obstetrics and gynecology. 2018;219(1):40-51. doi:10.1016/j.ajog.2017.12.231.

29. Davenport M, Mach KE, Shortliffe LMD, Banaei N, Wang TH, Liao JC. New and developing diagnostic technologies for urinary tract infections. Nature reviews Urology. 2017;14(5):296-310. doi:10.1038/nrurol.2017.20. 30. Durojaiye CO, Healy B. Urinary tract infections: diagnosis and management. Prescriber. 2015;26(11):21-9. doi:10.1002/psb.1362.

31. Edefonti A, Tel F, Testa S, De Palma D. Febrile urinary tract infections: clinical and laboratory diagnosis, imaging, and prognosis. Semin Nucl Med. 2014;44(2):123-8.

doi:https://dx.doi.org/10.1053/j.semnuclmed.2013.10.004.

32. Eriksen SV, Bing-Jonsson PC. Can we trust urine dipsticks? Norwegian Journal of Clinical Nursing / Sykepleien Forskning. 2017:1-14. doi:10.4220/Sykepleienf.2016.58641.

33. Masajtis-Zagajewska A, Nowicki M. New markers of urinary tract infection. Clin Chim Acta. 2017;471:286-91. doi:https://dx.doi.org/10.1016/j.cca.2017.06.003.

34. Rogozínska E, Formina S, Zamora J, Mignini L, Khan KS, Rogozińska E. Accuracy of Onsite Tests to Detect Asymptomatic Bacteriuria in Pregnancy: A Systematic Review and Meta-analysis. Obstetrics \& Gynecology. 2016;128(3):495-503. doi:10.1097/aog.0000000000001597.

35. Matulay J, Mlynarczyk C, Cooper K. Urinary Tract Infections in Women: Pathogenesis, Diagnosis, and Management. Curr Bladder Dysfunct Rep. 2016(11):53-60. doi:DOI 10.1007/s11884-016-0351-.

36. Biardeau X, Corcos J. Intermittent catheterization in neurologic patients: Update on genitourinary tract infection and urethral trauma. Ann Phys Rehabil Med. 2016;59(2):125-9. doi:https://dx.doi.org/10.1016/j.rehab.2016.02.006.

37. Dorney K, Bachur RG. Febrile infant update. Current Opinion in Pediatrics. 2017;29(3):280-5. doi:10.1097/mop.0000000000000492.

38. Stapleton AE. Urine Culture in Uncomplicated UTI: Interpretation and Significance. Current infectious disease reports. 2016;18(5):15. doi:10.1007/s11908-016-0522-0.

39. Shang YJ, Wang QQ, Zhang JR, Xu YL, Zhang WW, Chen Y et al. Systematic review and meta-analysis of flow cytometry in urinary tract infection screening. Clin Chim Acta. 2013;424:90-5.

doi:https://dx.doi.org/10.1016/j.cca.2013.05.014.

40. Kranz J, Schmidt S, Lebert C, Schneidewind L, Mandraka F, Kunze M et al. The 2017 Update of the German

Clinical Guideline on Epidemiology, Diagnostics, Therapy, Prevention, and Management of Uncomplicated Urinary

Tract Infections in Adult Patients. Part II: Therapy and Prevention. Urologia internationalis. 2018;100(3):271-8. doi:10.1159/000487645.

41. Burillo A, Bouza E. Use of rapid diagnostic techniques in ICU patients with infections. BMC Infect Dis. 2014;14:593. doi:https://dx.doi.org/10.1186/s12879-014-0593-1.

42. DeMarco ML, Ford BA. Beyond identification: emerging and future uses for MALDI-TOF mass spectrometry in the clinical microbiology laboratory. Clin Lab Med. 2013;33(3):611-28.

doi:https://dx.doi.org/10.1016/j.cll.2013.03.013.

43. Shaikh N, Borrell JL, Evron J, Leeflang MM. Procalcitonin, C-reactive protein, and erythrocyte sedimentation rate for the diagnosis of acute pyelonephritis in children. Cochrane Database of Systematic Reviews. 2015(1).

44. Dreger NM, Degener S, Ahmad-Nejad P, Wobker G, Roth S. Urosepsis--Etiology, Diagnosis, and Treatment. Dtsch. 2015;112(49):837-47; quiz 48. doi:https://dx.doi.org/10.3238/arztebl.2015.0837.

45. Ranjitkar P. Toilet Lab: Diagnostic Tests on Smart Toilets? Clinical Chemistry. 2018;64(7):1128-9.

doi:10.1373/clinchem.2018.286567. 